\title{
Costs and Returns of Angora Goat Enter- prises with and without Coyote Predation
}

\author{
JERRY H. SCRIVNER AND J. RICHARD CONNER
}

\begin{abstract}
During 1980, 101 ranchers in 3 counties (Bosque, Hamilton, and Coryell) in Texas, were interviewed regarding livestock losses and expenses resulting from methods used to reduce predation. Using data from the survey and other primary and secondary sources, 2 cost/return budgets were developed for nanny (female), wether (castrated males), and nanny/wether goat operations typical to the study area. First, budgets representing the 3 types of operations in the absence of predation were developed. Then, using an average of the predation rates and levels of prevention practices revealed by the survey, budgets were developed to represent the 3 types of operations with predation. Predation reduced gross revenues for nanny, nanny/wether, and wether goat operations by $22.2 \%$, $14.3 \%$, and $13.5 \%$, respectively, when predation was a problem. Fewer saleable goats and pounds of mohair were the major reasons for this decrease in revenues. Also, when predation was a problem, operational costs were increased by $32.8 \%, 17.7 \%$, and $16.4 \%$ for nanny, nanny/wether, and wether goat operations, respectively. Factors which accounted for the majority of this increase included extra feed, travel expenses, and labor primarily associated with predator control efforts and penning, kidding, and extra surveillance of goats because of the presence of predators. The results illustrate the importance of costs due to attempts to reduce predation. These costs may equal or exceed the value of animals killed by predators; however, without these added costs predation losses likely would be greater.
\end{abstract}

Predation, primarily by coyotes (Canis latrans), has long been a problem to the livestock industry (Delorenzo and Howard 1976, Klcbenow and McAdoo 1976, Nesse et al. 1976, Nass 1977). Such losses often result in a substantial reduction in cash returns to ranchers (Nesse et al. 1976, Taylor et al. 1978, Texas Crop and Livestock Reporting Service 1979, Wade and Connolly 1980). For the sheep industry, the U.S. Fish and Wildlife Service (1978)

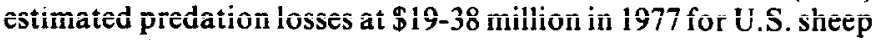
producers in the 17 western states. Meanwhile, consumers lost $\$ 4$ million in benefits because of reduced quantities and higher prices for lambs available.

In Texas, the number of sheep has declined from 10.8 million in 1943 to 2.4 million in 1980 . The number of goats has declined from 4.1 million in 1965 to 1.4 million in 1980. A significant factor contributing to the decline of the Texas sheep and goat industry is predation (Kensing 1978, 1980). The Texas Crop and Livestock Reporting Service (1979) estimated that in 1978 predators accounted for $5 \hat{\mathbf{8}} \overline{\%}$ of aî sheep and liamb losses and $\overline{7} \overline{2} \%$ of all goat and kid losses in Texas. About $\$ 13$ million or $62 \%$ of the total market value of sheep, lamb, goat, and kid losses was due to predators.

Most researchers determine the cost of predation to ranchers by calculating 1 or 2 cost factors, such as the value of livestock killed by predators and/or direct costs associated with predator control such as traps or fees paid professional trappers (Nesse et al. 1976,

\footnotetext{
Authors are graduate research assistant, Department of Wildlife and Fisheries Sciences and professor, Departments of Agricultural Economics and Range Science, Texas A\&M University, College Station 77843. Approved by the Director, Texas Agricultural Experiment Station as TA-18221.

Authors appreciate Drs. Samuel L. Beasom, Milo J. Shult, and Dale A. Wade for their review of an earlier draft of this manuscript, and also acknowledge the helpful comments of Dr. J. Juan Spillett and Mr. Guy E. Connolly and L. Charles Howard, Jr., during the course of this research.

Received for publication November 29, 1982
}

Texas Crop and Livestock Reporting Service 1979). Other costs, however, should be considered. These include expenses associated with management to protect livestock from predators such as night-time penning of livestock, shed-lambing or kidding ${ }^{1}$, and the use of guard dogs and scare devices (such as propane and acetylene exploders). Costs associated with one or more of these techniques include additional transportation, feed, labor, and equipment over the amount which would be used in the absence of predation.

The financial impact of depredation on the typical production firm can be examined with enterprise budgets (Gee 1978). By evaluating livestock costs and returns for operations with and without predation, the effect of specific levels of predation on representative livestock operations easily can be seen. Furthermore, enterprise budgets can be used to illustrate the financial effects of changes in loss rates and/or control methods on the economic viability of a livestock operation.

Studies which use enterprise budgets to evaluate the cost of predation to Angora goat ranchers are lacking, although Wade and Connolly (1980) have addressed some of the economics involved. The objective of this study was to develop enterprise budgets of typical Angora goat operations with current levels of predation and control methods. These budgets then are compared to budgets for the same operations with no predation and predator control and budgets which reflect current control levels but reduced levels of predation.

\section{Methods}

The study area included Bosque, Hamilton, and Coryell counties in Texas. The 3 adjacent counties are in the Grand Prairie land resource area (Rechenthin and Smith 1967). The soils, mostly fine textured, are derived from limestone and marls. The original vegetation consisted of primarily tall and mid-grass prairie but honey

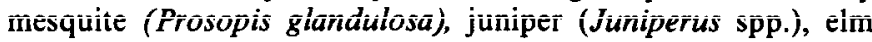
(Ulmus spp.), and oak (Quercus spp.), now have thickened to dense stands on many acres.

These 3 counties are just outside the northeastern edge of the Edwards Plateau. In such counties the annual coyote abundance survey (Roughton 1976) has continually recorded high coyote densities and they reportedly have high goat losses to predators (Pearson and Caroline 1981). These counties were selected for study because of the high probability of finding ranchers with predation problems. During 1968-1981, the number of Angora goats decreased $\overline{8} 5 \%, \overline{8} i \overline{\%}$, and $65 \%$ for Bosque, Coryeli Hamilton counties, respectively, while the statewide decrease was 67\% (Texas Crop and Livestock Reporting Service 1968-1981).

In 1981, ranchers in the study area were questioned regarding their costs due to predation for the 1980 calender year. Ranch operations were classified according to herd size and herd composition. Nanny $(\mathrm{N})$ operations consisted of more than 10 nannies with $\leq 10$ male goats; wether (W) operations had more than 10 wethers with $\leq 10$ nannies; and nanny/wether $(N / W)$ operations had $>10$ nannies and 10 wethers. The number and percent of

1Shed-lambing and kidding is used for protection from inclement weather, disease, and nutritional deficiencies. We only consider this management alternative as a cost due to predation when the technique would not be used if predators were not a problem. 
ranchers questioned in each category for the 3 counties are listed in Tabile $\mathbf{1}$.

Table 1. Number and percent of ranchers personally interviewed in Bosque, Hamilton, and Coryell counties. Ranch operations were classified as nanny, nanny/wether, and wether.

\begin{tabular}{lcccccccc}
\hline \hline & \multicolumn{2}{c}{ Nanny } & & \multicolumn{2}{c}{ Nanny/Wether } & & \multicolumn{2}{c}{ Wether } \\
\cline { 2 - 3 } & Number & Percent & & Number & Percent & & Number & Percent \\
\hline Bosque & 4 & 18 & & 12 & 18 & & 5 & 36 \\
Hamilton & 7 & 32 & & 31 & 48 & & 2 & 14 \\
Coryell & 11 & 50 & & 22 & 34 & & 7 & 50 \\
$\quad$ Total & 22 & 100 & & 65 & 100 & & 14 & 100 \\
\hline
\end{tabular}

Kanchers were questioned regarding costs resulting from livestock losses to predators and management techniques used to reduce losses. Cost factors included: (1) the number and percent of kids and adults killed by predators and the number and percent of adults dying from causes other than predation, (2) the amount and types of predator control equipment owned by the rancher as well as hours and mileage used for predator control, (3) dollars spent supporting a full or part-time trapper, (4) the value of feed and the number of kilometers driven and hours spent penning, kidding, and checking goats above which would have been used if predators were not a problem, (5) dollars spent on scare devices, and (6) the number of livestock guarding dogs.

The price/head of goats and pounds of mohair for investment requirements and production revenue were determined by exâniñing March and April market reports for a 5-year period (Texas Sheep and Goat Raisers Association 1978-1982). Each price then was adjusted to 1982 dollars by using a production price index for each year (U.S. Department of Agriculture 1979-1980, 1980-1982). A mean price/item then was calculated using the 5 adjusted values. Prices for other investment requirements and fixed and variable inputs were determined using information provided by the Texas Agricultural Extension Service (1982) and appropriate businesses in the study region.

Table 2 describes a typical management activities for calender for Angora goats in Bosque, Hamilton, and Coryell counties. This management scheme provided a framework on which the goat budgets were built. Revenue and input allocation were based on a production year beginning in October. Obviously for W operations, many of these activities do not occur. During unspecified time periods the primary activity involves observing livestock. Throughout production year, miscellaneous activities also occur, such as repairing fences and water systems and feeding salt and minerals.

Expected costs and returns based on this production system were used to develop a budget for each of the 3 types of operations in the absence of predation. In these budgets, the only survey data used included the expected percent kid crop in the absence of predation and the percent of adult animals dying to causes other than predation. On the average, ranchers with $N$ and $N / W$ operations expected a $73 \%$ kid crop $(n=15)$ in the absence of predation. This is similar to kid crop figures once reported by ranchers in arcas wherc formcrly predators were not a problem or where grazing by goats has traditionally been at moderate intensities (Bassett 1983 and Shelton 1983). The percent of adult goats dying to causes other than predation was $6.58 \%(\mathrm{~N}), 3.23 \%(\mathrm{~N} / \mathrm{W})$, and $1.13 \%(\mathrm{~W})$. Using survey results, a second budget then was generated for each operation by adjusting cost/return factors to reflect average changes resulting from predation. For each budget, costs resulting from livestock losses to predators and techniques used to reduce predation were averaged based on total number of adults and then converted to cost/animal unit (AU). The average herd size was 113 for $N$ operations; 141 nannies and 170 wethers for $\mathrm{N} / \mathrm{W}$ operations; and 221 for $\mathrm{W}$ operations. Obviously, the total number of goats and animal units fluctuates throughout the year because of kidding, death losses, and sales. However, to be consistent, all AU costs were calculated on the basis of the total number on hand at the beginning of each production year, which is assumed to be constant over years with and without predation.

\section{Results and Discussion}

Tables 3, 4, and 5 list the costs and returns/ $A U$ for $N, N / W$, and W operations, respectively, when coyote predation was and was not a problem. For all 3 budgets, investment requirements increased when predation was a problem due to the cost of purchasing a livestock guarding $\mathrm{dog}$. There was an average of $0.32(\mathrm{~N})$, $0.36(\mathrm{~N} / \mathrm{W})$, and $0.36(\mathrm{~W})$ guard dogs for the 3 operations. Most dogs purchased were Komondork and Great Pyrenees. Green et al. (1980) reported the average value of such dogs to be $\$ 500.00$; thus, investment requirements increased $\$ 5-10.00 / \mathrm{AU}$ for each budget.

An average of $3.52 \%(\mathrm{~N}), 4.18 \%(\mathrm{~N} / \mathrm{W})$, and $12.21 \%(\mathrm{~W})$ of the adult goats were estimated to be killed by predators. Coyotes prefer young Angora kids to adults (Guthery and Beasom 1977), therefore the greater percent of adults killed for $W$ operations was possibly because of the absence of kids in these operations. Thus, because of predation losses, total losses increased from $6.58 \%(\mathrm{~N})$, $3.23 \%(\mathrm{~N} / \mathrm{W})$, and $1.13 \%(\mathrm{~W})$ to $10.10 \%(\mathrm{~N}), 7.41 \%(\mathrm{~N} / \mathrm{W})$, and $13.34 \%(\mathrm{~W})$. There was an average of $22.61 \%(\mathrm{~N})$ and $20.32 \%$ (N/W) kids reported killed. The kid crop, therefore, decreased from an expected $73 \%$ for the $\mathrm{N}$ and $\mathrm{N} / \mathrm{W}$ operations to $50.4 \%$ and $52.7 \%$, respectively. Because of these losses, fewer pounds of adult and kid mohair and fewer kids and salvage adult goats were available to be marketed. As a result production revenues decreased $22.5 \%(\mathrm{~N}), 14.4 \%(\mathrm{~N} / \mathrm{W})$, and $13.5 \%(\mathrm{~W})$.

When predators are a problem, ranchers often use feed to lure goats from pasture to pen, as supplemental feed for grazing time lost due to penning or shed-kidding, and to attract goats so they can be inspected for wounds caused by predators. Costs and returns resulting from the possibility of stocking more goats/ha because of increased uses of supplemental feed with increased

Table 2. A typical management activities calendar for Angora goats in Bosque, Hamilton, and Coryell counties, Texas.

\begin{tabular}{|c|c|c|c|c|c|c|c|c|c|c|c|c|}
\hline \multirow[b]{2}{*}{ Activity } & \multicolumn{12}{|c|}{ Months } \\
\hline & $\mathbf{O}$ & $\mathbf{N}$ & D & 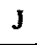 & $\mathbf{F}$ & $\mathbf{M}$ & A & $\mathbf{M}$ & $\mathbf{J}$ & $\mathbf{J}$ & $\mathbf{S}$ & $\mathbf{s}$ \\
\hline Billies are with nanny flock. & $\mathbf{x}$ & $\mathrm{X}$ & $\mathrm{X}^{1}$ & & & & & & & & & \\
\hline Goats are supplementally fed. & & $\mathrm{x}$ & $\mathrm{X}$ & $\mathbf{X}$ & $\mathbf{X}$ & $\mathbf{X}$ & & & & & & \\
\hline $\begin{array}{l}\text { Nannies, wethers, and yearlings are penned, sheared, and } \\
\text { drenched and sprayed for parasites. }\end{array}$ & & & & & $\mathbf{X}$ & & & & & & & \\
\hline Culls and yearlings are sold. & & & & & $\mathbf{X}$ & & & & & & & \\
\hline Kidding season. & & & & & & $\mathbf{X}$ & $\mathbf{X}^{1}$ & & & & & \\
\hline $\begin{array}{l}\text { Kids are penned, drenched, and marked for identification; kid } \\
\text { billies are castrated. }\end{array}$ & & & & & & & & & $\mathbf{X}$ & & & \\
\hline $\begin{array}{l}\text { Nannies and wethers are penned, sheared, drenched and sprayed. } \\
\text { Kids are sheated and sprayed. }\end{array}$ & & & & & & & & & & $\mathbf{X}$ & & \\
\hline
\end{tabular}

'Activity ends the middle of the month. 
predation were considered negligible and were not considered in this analysis. For the $\mathrm{N}, \mathrm{N} / \mathrm{W}$, and $\mathrm{W}$ operations, ranchers spent an average of $\$ 19.14 / \mathrm{AU}, \$ 9.62 / \mathrm{AU}$, and $\$ 13.93 / \mathrm{AU}^{2}$, respectively, for extra feed used during penning, kidding, and checking goats. Whereas predators resulted in fewer goats to feed (thereby reducing feed costs), the net effect was a cost increase because of the feed used in management techniques designed to reduce predation. Other operating costs such as veterinary medicine, shearing, and sales commission decreased slightly as a result of predation.

Miscellaneous costs increased for two reasons. First, for the N, $\mathrm{N} / \mathrm{W}$, and $\mathrm{W}$ operations, ranchers spent an average of $\$ 3.01 / \mathrm{AU}$, $\$ 2.12 / \mathrm{AU}$, and $\$ 2.97 / \mathrm{AU}$, respectively, supporting a full or part-

2We cannot explain why feed costs were higher for $\mathrm{W}$ operations than for $\mathrm{N} / \mathrm{W}$ operations. One would expect costs to be greater for $\mathrm{N} / \mathrm{W}$ operations because of higher nutritional requirements of nannies. time trapper. When ranchers paid trapper fees, it generally was because they participated in the federal-state cooperative Animal Damage Control program. Rancher fees usually were based on number of goats owned or number of acres in the operation. The second reason for a miscellaneous cost increase was because of guard dogs. Green et al. (1980) estimated the average cost/ year to maintain a livestock guarding dog to be $\$ 275$. This cost includes feed, veterinary fees and drugs, and miscellaneous items. For each of the 3 operations the cost/AU was estimated to be $\$ 4.67(\mathrm{~N})$, $\$ 1.91(\mathrm{~N} / \mathrm{W})$, and $\$ 2.69(\mathrm{~W})$.

Transportation costs accounted for a significant portion of the increase in operating inputs. Annually, ranchers drove an average of $2,234.86(\mathrm{~N}), 2,287.84(\mathrm{~N} / \mathrm{W})$, and $2,872.55(\mathrm{~W}) \mathrm{km}$ valued at $\$ 16.96 / \mathrm{AU}, \$ 6.31 / \mathrm{AU}$, and \$11.15/AU, respectively, for personal efforts made controlling predators (such as setting traps, snares,

Table 3. Annual costs and returns per animal unit of Angora goats in the absence and presence of predators for a nanny operation.

\begin{tabular}{|c|c|c|c|c|}
\hline \multirow[b]{2}{*}{$\begin{array}{l}\text { Investment Requirements } \\
\text { Yearling doe } \\
\text { Does } \\
\text { Bucks } \\
\text { Horse } \\
\text { Guard dog } \\
\text { Total }\end{array}$} & \multicolumn{2}{|c|}{ Absence of Predators } & \multicolumn{2}{|c|}{ With Predators } \\
\hline & $\begin{array}{c}\text { Number head } \\
1.03 \\
5.15 \\
0.10 \\
0.02 \\
0.00\end{array}$ & $\begin{array}{c}\text { Value/AU } \\
\$ 60.49 \\
376.16 \\
18.26 \\
20.00 \\
0.00 \\
\$ 474.91\end{array}$ & $\begin{array}{c}\text { Number head } \\
1.03 \\
5.15 \\
0.10 \\
0.02 \\
0.02\end{array}$ & $\begin{array}{l}\text { Value/AU } \\
\$ 60.49 \\
376.16 \\
18.26 \\
20.00 \\
10.00 \\
\$ 484.91\end{array}$ \\
\hline $\begin{array}{l}\text { Production } \\
\text { Adult mohair } \\
\text { Kid mohair } \\
\text { Kids } \\
\text { Does } \\
\quad \text { Total }\end{array}$ & $\begin{array}{l}\text { Number } \\
107.12 \mathrm{~kg} \\
29.01 \mathrm{~kg} \\
2.56 \text { head } \\
0.69 \text { head }\end{array}$ & $\begin{array}{l}\text { Returns/AU } \\
\$ 224.97 \\
98.96 \\
150.35 \\
22.08 \\
\$ 496.36\end{array}$ & $\begin{array}{l}\text { Number } \\
105.16 \mathrm{~kg} \\
19.86 \mathrm{~kg} \\
1.38 \text { head } \\
0.51 \text { head }\end{array}$ & $\begin{array}{l}\text { Returns/AU } \\
\$ 220.85 \\
67.76 \\
81.05 \\
16.32 \\
\$ 385.98\end{array}$ \\
\hline $\begin{array}{l}\text { Operating inputs } \\
\text { Supplement } \\
\text { Salt \& mineral } \\
\text { Sales commission } \\
\text { Vet. medicine } \\
\text { Shearing } \\
\text { Misc. expense } \\
\text { Equip., fuel, \& lube } \\
\text { Equip. repairs } \\
\text { Total }\end{array}$ & $\begin{array}{l}\text { Units } \\
504.86 \mathrm{~kg} \\
132.28 \mathrm{~kg} \\
3.25 \mathrm{head}\end{array}$ & $\begin{array}{l}\text { Costs/AU } \\
\$ 24.50 \\
10.80 \\
3.25 \\
3.92 \\
23.84 \\
10.00 \\
3.29 \\
0.41 \\
\$ 80.01\end{array}$ & $\begin{array}{l}\text { Units } \\
890.67 \mathrm{~kg} \\
132.28 \mathrm{~kg} \\
3.09 \text { head }\end{array}$ & $\begin{array}{l}\text { Costs/AU } \\
\$ 43.23 \\
10.80 \\
3.09 \\
3.54 \\
20.73 \\
17.68 \\
20.25 \\
2.52 \\
\$ 121.84\end{array}$ \\
\hline $\begin{array}{l}\text { Capital investment } \\
\text { Equipment } \\
\text { Livestock } \\
\text { Total }\end{array}$ & $\begin{array}{l}\text { Dollars invested } \\
\$ 188.14 \\
474.91\end{array}$ & $\begin{array}{l}\text { Costs/AU } \\
\$ 28.22 \\
71.24 \\
\$ 99.46\end{array}$ & $\begin{array}{l}\text { Dollars invested } \\
\$ 188.85 \\
484.91\end{array}$ & $\begin{array}{l}\text { Costs/AU } \\
\$ 28.33 \\
72.74 \\
\$ 101.07\end{array}$ \\
\hline $\begin{array}{l}\text { Ownership costs (Deprecia } \\
\text { Equipment } \\
\text { Livestock } \\
\text { Total }\end{array}$ & $\begin{array}{l}\text { xes, and insurance) } \\
\qquad \$ 26.88\end{array}$ & 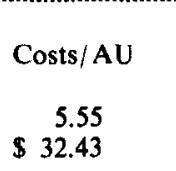 & . & $\begin{array}{l}\text { Costs } / \mathrm{AU} \\
\$ 26.98 \\
6.31 \\
\$ 33.29\end{array}$ \\
\hline $\begin{array}{l}\text { Labor costs } \\
\text { Equipment } \\
\text { Livestock } \\
\text { Total }\end{array}$ & $\begin{array}{c}\text { Hours Labor } \\
1.40 \\
8.00\end{array}$ & $\begin{array}{l}\text { Costs/AU } \\
\text { \& } 5.60 \\
32.00 \\
\$ 37.60\end{array}$ & $\begin{array}{c}\text { Hours Labor } \\
3.87 \\
19.23\end{array}$ & $\begin{array}{l}\text { Costs/AU } \\
\text { \$ } 13.76 \\
78.64 \\
\$ 92.40\end{array}$ \\
\hline $\begin{array}{l}\text { Land costs } \\
\text { Pasture rent } \\
\text { Total }\end{array}$ & $\begin{array}{c}\text { Hectares } \\
6.07\end{array}$ & $\begin{array}{l}\text { Costs/AU } \\
\$ 52.50 \\
\$ 52.50\end{array}$ & $\begin{array}{c}\text { Hectares } \\
6.07\end{array}$ & $\begin{array}{l}\text { Costs/AU } \\
\$ 52.50 \\
\$ 52.50\end{array}$ \\
\hline Residual Returns & & $\$ 194.36$ & & $\$-15.12$ \\
\hline
\end{tabular}


and $M-44 s$ ) and penning, kidding, and checking goats. Equipment repair costs increased proportionately.

For all 3 operations there was a slight increase in capital investment and ownership costs when predators were a problem. This was because of costs associated with predator control equipment owned by ranchers and purchase of guard dogs, respectively. In contrast, operator labor costs increased an average of $258.00(\mathrm{~N})$, $405.71(\mathrm{~N} / \mathrm{W})$, and $211.36(\mathrm{~W})$ hours valued at $\$ 54.82 / \mathrm{AU}$, $\$ 31.31 / \mathrm{AU}$, and $\$ 22.95 / \mathrm{AU}$, respectively. When predators are a problem, extra labor accounted for the single greatest increase in production costs. This was because of rancher's personal efforts in controlling predators and penning, kidding, and checking goats. In all, production costs increased $32.8 \%(\mathrm{~N}), 17.7 \%(\mathrm{~N} / \mathrm{W})$, and $16.4 \%(\mathrm{~W})$ as a result of efforts made to reduce predation.

While $\mathbf{N}$ operations have the potential for greatest profits, net returns for this type of operation decline most when predators are a problem (\$194.36 to \$-15.12). Economically, W operations were the least affected by predation. One obvious problem with such an operation, however, is that residual returns are negative even in the absence of predation. While the potential for monetary profit appears marginal for such operations, ranchers may also measure profit using other standards, such as benefits accrued from the use

Table 4. Annual costs and returns per animal unit of Angora goats in the absence and presence of predators for a nanny/wether operation.

\begin{tabular}{|c|c|c|c|c|}
\hline & \multicolumn{2}{|c|}{ Absence of Predators } & \multicolumn{2}{|c|}{ With Predators } \\
\hline $\begin{array}{l}\text { Investment requirements } \\
\text { Yearling doe } \\
\text { Yearling wether } \\
\text { Does } \\
\text { Wethers } \\
\text { Bucks } \\
\text { Horse } \\
\text { Guard dog } \\
\text { Total }\end{array}$ & $\begin{array}{c}\text { Number head } \\
\text { Number head } \\
0.46 \\
0.69 \\
2.32 \\
2.81 \\
0.05 \\
0.02 \\
0.00\end{array}$ & $\begin{array}{c}\text { Value/AU } \\
\$ 27.02 \\
40.52 \\
169.45 \\
228.51 \\
9.13 \\
20.00 \\
0.00 \\
\$ 494.63\end{array}$ & $\begin{array}{c}\text { Number head } \\
\text { Number head } \\
0.46 \\
0.69 \\
2.32 \\
2.81 \\
0.05 \\
0.02 \\
0.01\end{array}$ & $\begin{array}{c}\text { Value/AU } \\
\$ 27.02 \\
40.52 \\
169.45 \\
228.51 \\
9.13 \\
20.00 \\
5.00 \\
\$ 499.63\end{array}$ \\
\hline $\begin{array}{l}\text { Production } \\
\text { Adult mohair } \\
\text { Kid mohair } \\
\text { Kid goats } \\
\text { Does } \\
\text { Wethers } \\
\text { Total }\end{array}$ & $\begin{array}{l}\text { Number } \\
125.31 \mathrm{~kg} \\
13.07 \mathrm{~kg} \\
0.66 \mathrm{head} \\
0.39 \text { head } \\
0.33 \text { head }\end{array}$ & $\begin{array}{l}\text { Returns/AU } \\
\$ 263.17 \\
44.59 \\
38.76 \\
12.48 \\
10.90 \\
\$ 369.90\end{array}$ & $\begin{array}{l}\text { Number } \\
122.56 \mathrm{~kg} \\
9.44 \mathrm{~kg} \\
0.19 \mathrm{head} \\
0.29 \text { head } \\
0.21 \text { head }\end{array}$ & $\begin{array}{l}\text { Returns/AU } \\
\$ 257.42 \\
32.19 \\
11.16 \\
9.28 \\
6.93 \\
\$ 316.98\end{array}$ \\
\hline $\begin{array}{l}\text { Operating inputs } \\
\text { Supplement } \\
\text { Salt \& mineral } \\
\text { Sales commission } \\
\text { Vet. medicine } \\
\text { Shearing } \\
\text { Misc. expense } \\
\text { Equip., fuel \& lube } \\
\text { Equipment repair } \\
\text { Total }\end{array}$ & $\begin{array}{l}\text { Units } \\
447.54 \mathrm{~kg} \\
132.28 \mathrm{~kg} \\
1.38 \text { head }\end{array}$ & $\begin{array}{l}\text { Costs/AU } \\
\$ 21.72 \\
10.80 \\
1.38 \\
3.46 \\
19.12 \\
10.00 \\
2.84 \\
0.36 \\
\$ 69.68\end{array}$ & $\begin{array}{l}\text { Units } \\
639.34 \mathrm{~kg} \\
132.28 \mathrm{~kg} \\
0.69 \mathrm{head}\end{array}$ & $\begin{array}{l}\text { Costs/AU } \\
\$ 31.03 \\
10.80 \\
0.69 \\
3.25 \\
17.59 \\
14.03 \\
9.15 \\
1.16 \\
\$ 87.70\end{array}$ \\
\hline $\begin{array}{l}\text { Capital investment } \\
\text { Equipment } \\
\text { Livestock } \\
\text { Total }\end{array}$ & $\begin{array}{l}\text { Dollars invested } \\
\$ 188.14 \\
494.63\end{array}$ & $\begin{array}{l}\text { Costs/AU } \\
\$ 28.22 \\
74.19 \\
\$ 102.41\end{array}$ & $\begin{array}{l}\text { Dollars invested } \\
\$ 188.66 \\
499.63\end{array}$ & $\begin{array}{l}\text { Costs/AU } \\
\$ 28.30 \\
74.94 \\
\$ 103.24\end{array}$ \\
\hline $\begin{array}{l}\text { Ownership costs (Deprec } \\
\text { Equipment } \\
\text { Livestock } \\
\text { Total }\end{array}$ & and insurance) & $\begin{array}{l}\text { Costs/AU } \\
\$ 26.88 \\
3.61 \\
\$ 30.49\end{array}$ & & $\begin{array}{l}\text { Costs/AU } \\
\text { \$ } 26.95 \\
4.26 \\
\text { \$ } 31.21\end{array}$ \\
\hline $\begin{array}{l}\text { Labor costs } \\
\text { Equipment } \\
\text { Livestock } \\
\text { Total }\end{array}$ & $\begin{array}{l}\text { Hours labor } \\
1.21 \\
6.90\end{array}$ & $\begin{array}{l}\text { Costs/AU } \\
\text { S } 4.84 \\
27.60 \\
\text { s } 32.44\end{array}$ & $\begin{array}{c}\text { Hours labor } \\
2.38 \\
13.56\end{array}$ & $\begin{array}{l}\text { Costs/AU } \\
\$ 9.52 \\
54.24 \\
\$ 63.76\end{array}$ \\
\hline $\begin{array}{l}\text { Land costs } \\
\text { Pasture rent } \\
\text { Total }\end{array}$ & $\begin{array}{c}\text { Hectares } \\
6.07\end{array}$ & $\begin{array}{l}\text { Costs/AU } \\
\$ 52.50 \\
\$ 52.50\end{array}$ & $\begin{array}{c}\text { Hectares } \\
6.07\end{array}$ & $\begin{array}{l}\text { Costs/AU } \\
\$ 52.50 \\
\$ 52.50\end{array}$ \\
\hline Residual Returns & & $\$ 82.38$ & & $\$-21.43$ \\
\hline
\end{tabular}


of goats for brush control. Numerous ranchers responded that as long as the goats "kept the brush down" the animals paid their own way, implying that ranchers thought biological brush control saved money which could otherwise be spent on chemical or mechanical means. Our budgets describe "average" operations. Costs and returns for specific range operations will vary according to management strategies based on individual preferences and circumstances. Also, while we have tried to eliminate some of the variability in goat and mohair prices by indexing and averaging prices over a 5-year period, residual returns for each type of operation will change as commodity and resource prices change.

Budgets are perhaps more accurately viewed in a relative sense. It is clear that the potential for profit is greater for $\mathrm{N}$ operations than for $\mathrm{W}$ operations. The relative potential for profit without predation and associated monetary losses with predation are consistent with views often expressed by W goat ranchers. Generally these individuals said they would rather have all or some nannies in preference to wethers, but the fear of losing all the kids to predators and the expectation that grown wethers are less vulnerable to predators influenced their decision as to operation type.

$\mathrm{N} / \mathrm{W}$ operations were somewhat intermediate to $\mathrm{N}$ and $\mathrm{W}$ operations with respect to net returns in the absence of predation. When predators are a problem, net returns were slightly less than for the $\mathrm{N}$ operations but were most like the $\mathrm{W}$ operation with regards to the difference in residual returns with and without coyote predation.

In general, current revenue losses and costs associated with techniques used to reduce predation resulted in negative net financial returns for all operations. Clearly, this can be only a short run situation. First, if the firm continues to sustain such losses, and if benefits derived from brush control are not sufficient to off-set these losses, then the firm will go out of business. This provides some evidence for the view that herd liquidations are often the

Table 5. Annual costs and returns per animal unit of Angora goats in the absence and presence of predators for a wether operation.

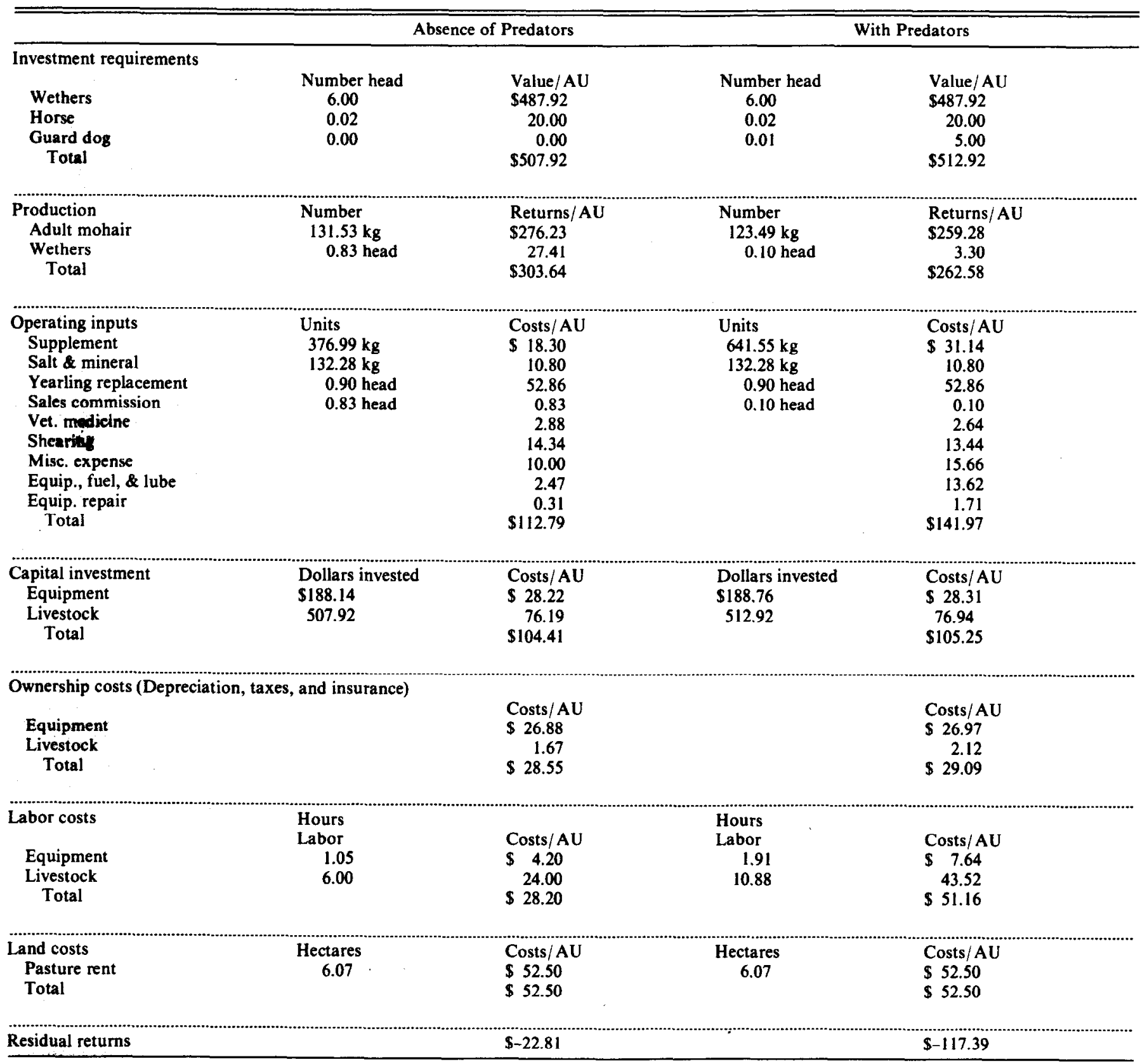


result of predator problems (Kensing 1978, 1980). Alternatively, the current level of predator control may eventually (within a year or two) result in lower levels of predation. This possibility is based on the assumption that the rate (or \%) of predation is at least partially a function of the level and/or type of predator control. If current level and/or types of control resulted in no predation, the net return for the $\mathrm{N}$ operation would be $\$ 95.26 / \mathrm{AU}^{3}$. If predator control reduced current predation losses by $1 / 2$, net returns would be $\$ 40.07 / \mathrm{AU}^{4}$. The other types of operations would be affected similarily. One significant point that emerges from this reasoning is the need to understand which techniques used to reduce predation are the most cost effective. Obviously, eliminating expenses on relatively inefficient control practices would reduce total costs, therefore, increasing net returns. Unfortunately, data regarding cost effectiveness for most techniques which reduce predation are lacking, probably because of difficulties in obtaining reliable data (Connolly 1982). Yet another possible means of increasing returns may be found in new or modifications of existing, production technologies and management practices. That is, since the presence of predators requires increased production costs, producers may be able to develop ways to allocate the additional operational costs so as to increase production output relative to output using existing technologies. While the use of more efficient technologies is a viable alternative in the long; in the short term such practical technologies are unlikely to emerge.

The use of enterprise budgets clearly illustrated the effect of predation on representative livestock operations. Not only can predation result in important economic losses resulting from livestock killed, but these results demonstrate the importance of costs associated with attempts to reduce predation. Such costs may equal or exceed the value of animals killed by predators; however, without these added costs predation losses likely would be greater. Also, studies which estimate the cost of predation by only determining the value of animals killed may greally underestimate the actual total cost of predation. These results further demonstrate the need for more information on the relative cost effectiveness of various types of predation control strategies.

3The difference betwen revenues without predation and production costs with predation.

'One-half the difference between revenues without predation and revenues with predation added to revenues with predation; this sum minus production costs with predation.

\section{Literature Cited}

Bassett, J.W. 1983. Personal communication. Animal Science Dep., Texas A\&M.

Connolly, G.E. 1982. On cost effectiveness of coyote control to protect livestock. p. 279-294. In: J.M. Peek, and P.D. Dalke (Eds.) WildlifeLivestock Relationship Symposium: Proc. 10. Univ. of Idaho, Forest, Wildlife and Range Exp. Sta., Moscow.

DeLorenzo, D.G., and V.W. Howard, Jr. 1976. Evaluation of sheep losses on a range lambing operation without predator control in southeastern New Mexico. Final Rep. to U.S. Fish and Wildl. Serv. Denver Center, New Mexico State Univ., Las Cruces.

Green, J.S., T.T. Tueller, and R.A. Woodruff. 1980. Livestock guarding dogs: economics and predator control. Rangelands 6:247-248.

Guthery, F.S., and S.L. Beasom. 1977. Effects of predator control on Angora goat survival in south Texas. J. Range. 31:168-173.

Kensing, R.H. 1980. The changing hill country. Texas Section, Soc. for Range Manage., Annual Meeting, Kerrville, Texas, Dec. 5, 1980. Mimeo.

Kensing, R.H. 1978. Economics of Angora goat enterprises. Texas Agr. Exp. Sta. Rep., Texas A\&M Univ. System, College Station.

Klebenow, D.A., and K. McAdoo. 1976. Predation on domestic sheep in northeastern Nevada. J. Range Manage. 29:96-100.

Ness, R.D. 1977. Mortality associated with sheep operations in Idaho. J. Range Manage. 30:254-258.

Nesse, G.E., W.M. Longhurst, and W.E. Howard. 1976. Predation and the sheep industry in California, 1972-1974. Univ. Calif. Div. Agr. Sci. Bull. 1878.

Pearson, E.W., and M. Caroline. 1981. Predator control in relation to livestock losses in Central Texas. J. Kange Manage. 34:435-441.

Rechenthin, C.A., and H.N. Smith. 1967. Grassland restoration: effect on water and supply. U.S. Dep. Agr., Soil Conserv. Serv., Temple, Texas.

Roughton, R.D. (Coordinator). 1976. Indices of predator abundance in the western United States, 1976. Prog. Rep. U.S. Dep. Inter., Fish and Wildl. Serv. Denver Wildl. Res. Center, Colo.

Shelton, M. 1983. Personal Communication. Texas Agr. Exp. Sta. Research Center, San Angelo.

Taylor, R.G., J.P. Workman, and J.E. Bowns. 1978. The economics of sheep predation in southwestern Utah. J. Range Manage. 32:317-321.

Texas Agricultural Extension Service. 1982. Texas enterprise budgets: Texas Cross Timbers Region. Texas Agr. Ext. Serv., Texas A\&M University System, College Station. Mimeo.

Texes Crop and Livestock Reporting Service. Reports for 1968-1981. Texas Dep. Agr., Austin, Texas.

Texas Crop and Livestock and Reporting Service. 1979. Texas sheep and goat losses and marketing practices. Texas Dep. Agr.

Texas Sheep and Goat Raisers Association. 1978-1982. Press Time Markets. The Ranch Magazine 1978-1982.

U.S. Department of Agriculture. Agricultural prices annual summary. U.S. Dep. Agr., Econ., Statist. and Coop. Serv. Annual Editions 1979. 1980 and Quarterly Releases 1981-1982. Washington, D.C.

U.S. Fish and Wildlife Service. 1978. Predator damage in the west: a study of coyote management alternatives. U.S. Dep. of Inter., Washington, D.C

Wade, D.A. and G.E. Connolly. 1980. Coyote predation on a Texas goat ranch. Texas Agricultural Prog. 26:12-16. 